\title{
Translation and Cultural Adaptation to European Portuguese of the "Measure of Moral Distress - Healthcare Professionals" Scale: A Cross-Sectional Multicenter Study
}

\author{
Tradução e Adaptação Cultural para Português Europeu do \\ Instrumento "Medida do Sofrimento Moral - Profissionais de \\ Saúde": Um Estudo Transversal Multicêntrico
}

Mónica DIAS $\otimes^{1}$ 1 , Carla TEIXEIRA ${ }^{1,2,3}$, Bárbara ANTUNES ${ }^{4}$

Acta Med Port 2022 Sep;35(9):624-632 - https://doi.org/10.20344/amp.16531

\section{ABSTRACT}

Introduction: Moral distress occurs when one knows the morally correct action to take but is constrained from taking that action. The aims of this study were to translate into European Portuguese and culturally adapt the "Measure of Moral Distress - Healthcare Professionals" questionnaire to the context of the Portuguese healthcare system and to explore the frequency and intensity of moral distress occurring among medical students.

Material and Methods: The "Measure of Moral Distress - Healthcare Professionals" questionnaire was translated and culturally adapted to European Portuguese, following the internationally accepted "COnsensus-based Standards for the selection of health Measurement INstruments". Afterwards, a web-based survey was conducted, following the "Checklist for Reporting Results of Internet E-Surveys" guidelines. Medical students were asked to rate potentially morally distressing situations on frequency and intensity.

Results: Of approximately 4300 medical students, 939 (22\%) completed the survey. Participants experienced, on average, 16 morally distressing situations. Median of composite score of moral stress was 79 (IQR $44-118$ ). Only $31 \%$ of the students felt well prepared to handle a morally distressing situation, $26 \%$ considered leaving medical school and $28 \%$ thought about choosing a non-clinical specialty due to moral distress.

Conclusion: Despite a plethora of studies on this topic, the results suggested that moral distress is still a common phenomenon among medical students with a cumulative effect over time. These results emphasize the importance of a critical review of medical education, reducing the harmful effects of preventable psychological phenomena in clinical practice and in the lives of future healthcare professionals.

Keywords: Health Personnel/psychology; Morals; Occupational Stress; Portugal; Psychometrics/instrumentation; Stress, Psychological; Students, Medical; Surveys and Questionnaires; Translating

\section{RESUMO}

Introdução: O sofrimento moral ocorre quando um profissional de saúde sabe qual a ação moralmente correta a adotar, mas identifica um obstáculo que o constrange de realizar. Os objetivos deste estudo foram traduzir para Português Europeu e adaptar culturalmente para o contexto do sistema de saúde Português o questionário "Measure of Moral Distress - Healthcare Professionals" e explorar a frequência e intensidade deste fenómeno entre estudantes de medicina.

Material e Métodos: Primeiro, traduzimos e adaptámos culturalmente para português Europeu o questionário "Measure of Moral Distress - Healthcare Professionals", seguindo o protocolo "COnsensus-based Standards for the selection of health Measurement INstruments". Depois, elaborámos um questionário seguindo as normas de orientação "Checklist for Reporting Results of Internet E-Surveys". Os estudantes de Medicina identificaram situações potencialmente causadoras de sofrimento moral em frequência e intensidade.

Resultados: De aproximadamente 4300 participantes, 939 (22\%) completaram o questionário. Os estudantes experienciaram, em média, 16 situações causadoras de sofrimento moral. A mediana da cotação composta de sofrimento moral foi 79 (IQR 44 - 118). Apenas $31 \%$ dos estudantes se sentem bem ou muito bem preparados para lidar com estas situações, $26 \%$ já consideraram deixar o curso de Medicina e $28 \%$ já pensaram escolher uma especialidade não clínica por este motivo.

Conclusão: Apesar de vários estudos na área, os resultados sugerem que o sofrimento moral é um fenómeno comum entre alunos de medicina e a sua experiência mostra um efeito cumulativo ao longo do tempo. Estes resultados enfatizam a importância de rever criteriosamente o currículo de educação médica, de forma a reduzir os danos de um fenómeno evitável na prática clínica e nas vidas dos futuros profissionais de saúde.

Palavras-chave: Estudantes de Medicina; Inquéritos e Questionários; Moral; Pessoal de Saúde/psicologia; Portugal; Psicometria/ instrumentação; Stress Ocupacional; Stress Psicológico; Tradução

\section{INTRODUCTION}

Moral distress was first described as a situation that occurs when a healthcare professional knows the morally

correct action to take but is constrained in some way from taking that action. ${ }^{1}$ Currently, a broader approach of moral

1. Instituto de Ciências Biomédicas Abel Salazar. University of Porto. Porto. Portugal.

2. Department of Anesthesiology and Intensive Care. Centro Hospitalar Universitário do Porto. Porto. Portugal.

3. CINTESIS - Center for Health Technology and Services Research. University of Porto. Porto. Portugal.

4. Primary Care Unit. Department of Public Health and Primary Care. University of Cambridge. Cambridge. United Kingdom.

$\triangle$ Autor correspondente: Mónica Dias. monica.dias 96@hotmail.com

Recebido/Received: 08/05/2021 - Aceite/Accepted: 13/09/2021 - Publicado Online/Published Online: 26/01/2022 - Publicado/Published: 01/09/2022

Copyright $\odot$ Ordem dos Médicos 2022 
distress has been adopted and can be considered as a psychological response to morally challenging situations, including moral conflict, dilemma, or uncertainty. ${ }^{2}$

Moral distress is frequent among healthcare professionals and seems to be increasing. ${ }^{3}$ It may cause physical and emotional symptoms ${ }^{4}$ and contribute to many undesirable effects, including burnout, decrease of wellbeing, lack of empathy and, ultimately, decrease of quality of care. ${ }^{5}$ Among healthcare professionals, those with more clinical experience face the "crescendo effect" phenomenon, ${ }^{6}$ meaning they have higher levels of moral distress due to the negative effects which have built up over time.

Medicine has undergone many changes over time and the doctor-patient relationship has gained relevance as one of the main subjects of medical discussions. ${ }^{7}$ This relationship requires a moral conduct from the physician to deal with moral issues and to do the right choices considering all circumstances. ${ }^{8,9}$ Many aspects of our lives influence the way we define ethical clinical practice, namely religion, philosophy and culture. ${ }^{7}$ A code of ethics helps healthcare professionals to deal with situations when they find barriers preventing them from fulfilling their duties, supporting them in their practice and reducing their moral distress. ${ }^{10}$

Medical students are vulnerable to moral distress due to their low position in the hospital hierarchy and their underdeveloped professional identity, ${ }^{11-13}$ but this is not widely recognized by medical educators, ${ }^{14}$ which may overwhelm medical schools' efforts to advance student's levels of empathy and contribute to the persistent lack of efficacy of ethics and humanities curricula. ${ }^{15}$

The Moral Distress Scale-Revised (MDS-R) ${ }^{16}$ was used by most recent studies evaluating moral distress in healthcare professionals. ${ }^{17-20}$ In a recent revision of the "Measure of Moral Distress - Healthcare Professionals (MMD-HP)" questionnaire, the authors recommended replacing the MSD-R as a measure for moral distress among healthcare professionals in order to include more sources of moral distress and simplify its use. ${ }^{21}$

The aims of this study were to translate into European Portuguese and culturally adapt the MMD-HP questionnaire ${ }^{21}$ to the context of the Portuguese healthcare system, and to explore the frequency and intensity of moral distress occurring among medical students in seven Portuguese medical schools.

\section{MATERIAL AND METHODS Study design}

A cross-sectional, multicenter study was conducted in medical students attending clinical years (fourth to sixth) using a web-based survey, as per the Checklist for Reporting Results of Internet E-Surveys (CHERRIES checklist). ${ }^{24}$ The study was approved by the ethics committees of seven medical schools: Faculdade de Medicina da Universidade do Porto (FMUP), Faculdade de Medicina da Universidade de Lisboa (FMUL), Faculdade de Medicina da Universidade de Coimbra, Instituto de Ciências Biomédicas Abel Salazar (ICBAS), Nova Medical School | Faculdade de Ciências
Médicas (NMS|FCM), Faculdade de Ciências da Saúde da Universidade da Beira Interior (UBI), Escola de Medicina da Universidade do Minho (UM).

\section{Measures}

The author of the MDS- $\mathrm{R}^{16}$ was contacted and recommended the use of the MMD-HP version of the questionnaire. ${ }^{21}$ Following the COSMIN checklist ${ }^{25}$ and guidelines and principles of good practice for this process, ${ }^{26,27}$ the original questionnaire was linguistically translated and culturally adapted to the context of the Portuguese healthcare system.

The initial translation of the MMD-HP from English into Portuguese was made by a physician and a researcher who was aware of the concepts used in this context and by an English teacher, with no experience in the subject. Afterwards, we created a final common version.

A retroversion to English of the translated Portuguese version was made in order to ensure content equivalence between the versions. It was performed by two physicians and a nurse, who were blind to the original version and fluent in English. We compared the versions and created a prefinal version.

The final Portuguese version was discussed in a focus group comprised of seven medical students and the first author, in order to ascertain the validity of the interpretation and achieve consensus on the best way to formulate each item and ensure there were no divergent interpretations. The interview guide used by the focus group is available as Appendix 1 (Appendix 1: https://www.actamedicaportuguesa.com/revista/index.php/amp/article/view/16531/Appendix_01.pdf).

Cronbach's alpha, $\alpha$, revealed a good internal consistency $(\alpha=0.89)$. The $\alpha$ value of the original instrument was $0.98 .{ }^{21}$ Any issues were identified after evaluating item-toitem correlations and changes to alpha calculations if certain items were deleted.

The Portuguese version of the questionnaire presented 27 potential distress situations. Students were asked to rate each situation in terms of the frequency and intensity on a 5-point numerical rating scale. If a student had never experienced a situation described in one or more items, we still asked them to rate the items by selecting zero regarding frequency and indicate how distressed they think they would feel if they had experienced it. There were free text boxes to allow addition of new situations. The Portuguese version of MMD-HP is available as Appendix 2 (Appendix 2: https://www.actamedicaportuguesa.com/revista/index.php/ amp/article/view/16531/Appendix_02.pdf).

Furthermore, we asked participants if they ever considered leaving medical school or if they ever considered choosing a non-clinical specialty due to moral distress and how well prepared they felt to handle a morally distressing situation. We also asked if such issues had been addressed during their medical education. One last free text item allowed participants to write any comments about the theme if they wished. The instrument included a definition of moral 
distress at the beginning.

The final questionnaire was made available online and the link sent by email to the participants, who were informed about the volunteer nature of the study; there were no incentives offered. Free, informed consent was obtained by each potential participant in the form of clicking a square next to the statement declaring the aim of the study, which also included their right to withdrawal at any point with no consequences. The questionnaire had 38 items sequentially presented and could only be submitted if all items were answered, except for the free text items. Data were collected between the 6th March 2020 and the 3rd April 2020. The complete survey is available as Appendix 3 (Appendix 3: https://www.actamedicaportuguesa.com/revista/index.php/ amp/article/view/16531/Appendix_03.pdf).

\section{Analysis}

Descriptive analysis was used to look at distribution of sociodemographic and categorical response data.

Analysis was performed using the two-tailed significance level set at $\alpha=0.05$. The frequency and intensity for each situation were first analyzed individually and then a composite item of moral distress (the product between the frequency and intensity of each factor), that ranged from 0 to 16 , was created in order to compare it with other variables. The resulting composite score based on 27 items has a range of $0-432$.

If data related with the composite score showed a skewed right distribution, the logarithm of the variable would
Table 1 - Demographics of the population

\begin{tabular}{lc}
\hline Number of participants, $\mathrm{n}$ & 939 \\
Age, median (IQR) & $23(22-24)$ \\
Gender, $\mathrm{n}(\%)$ & \\
Female & $739(79)$ \\
Male & $200(21)$ \\
Year of study, $\mathrm{n}(\%)$ & \\
$4^{\text {th }}$ & $186(20)$ \\
$5^{\text {th }}$ & $308(33)$ \\
$6^{\text {th }}$ & $445(47)$ \\
\hline
\end{tabular}

be used to normalize it and to perform the statistical tests. $T$ tests were performed to compare the composite score in different groups of participants. One-way ANOVA tests were performed when more than one group were being compared at the same time. The IBM SPSS software, version 26 (IBM corp., Armonk, N.Y.) was used.

\section{RESULTS}

Demographics of the population

Of approximately 4300 medical students (students from the fourth to the sixth year attending the academic year 2019/2020 in seven Portuguese medical schools), $939(22 \%)$ completed the survey. As shown in Table 1, 739 $(79 \%)$ of 939 participants were female, which is close to the gender division of the medical students in Portugal (about $70 \%$ female) and the median age was 23 [interquartile

$78.2 \%$ of the participants experienced at least 10 morally distressing situations

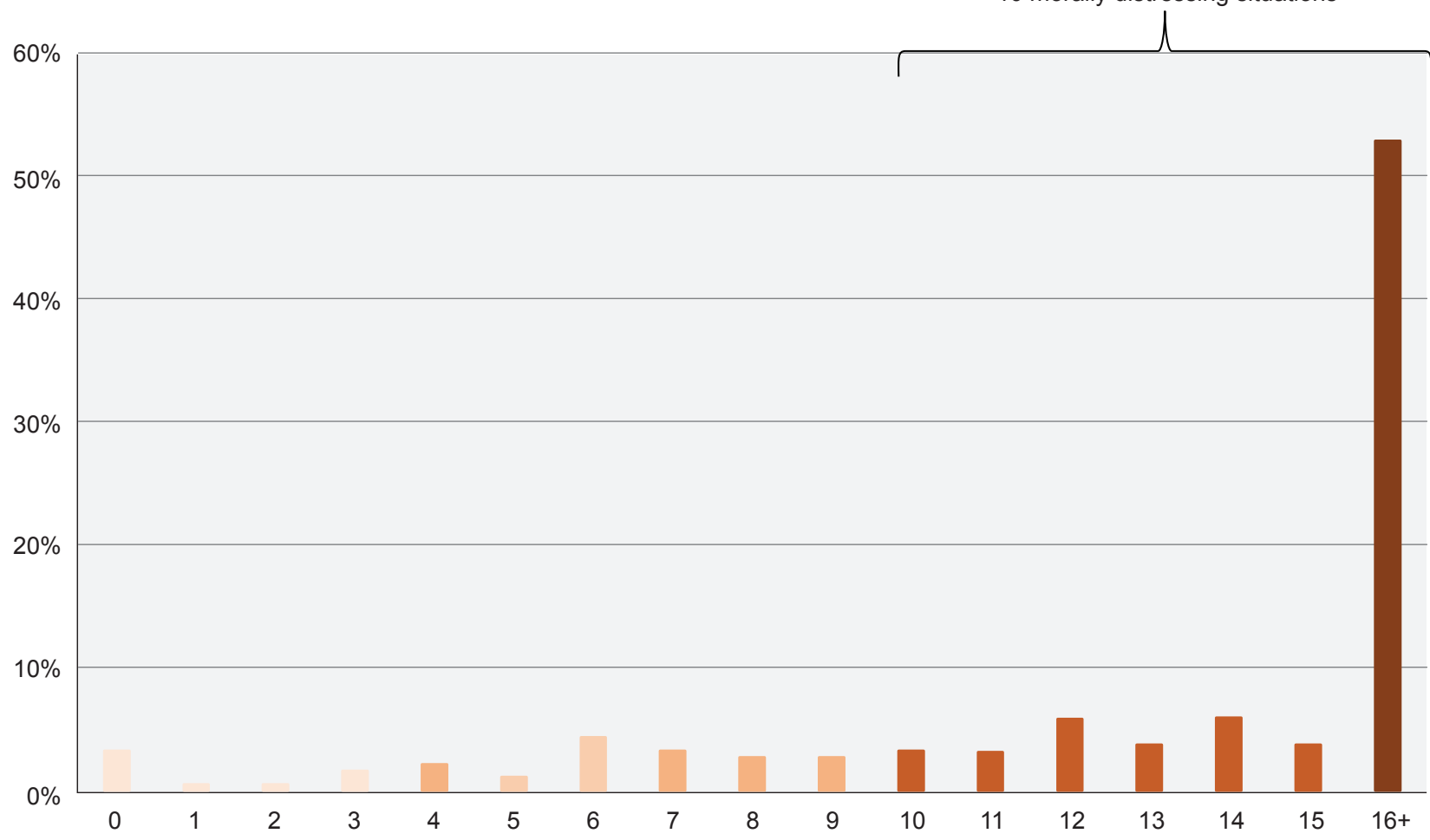

Figure 1 - Frequency of the number of morally distressing situations experienced by participants 
range (IQR) 22 - 24]. Of all participants, 186 (20\%) were from the fourth year, $308(33 \%)$ from the fifth and 445 (47\%) from the sixth year.

\section{Morally distressing situations: frequency and intensity}

Students experienced, on average, 16 morally distressing situations (minimum 0; maximum 27). Most students ( $n=496,53 \%$ ) experienced at least 16 situations. Only 30 (3\%) of them never experienced any situation (Fig. 1).

Table 2 presents the occurrence rates and intensity scores for each situation, including experienced and anticipated situations.

Less than $1 \%$ of all respondents $(n=5)$ reported other situations of moral distress concerning situations such as participation in abortion appointments and witnessing a patient suffering during diagnostic procedures.

The average composite score of moral distress was 79 (IQR 44-118).

\section{Handling a morally distressing situation}

Only $295(31 \%)$ of 939 respondents felt well or very well prepared to handle a morally distressing situation, 540 (58\%) felt poorly prepared and $99(11 \%)$ of the students did not feel prepared at all (Fig. 2). The majority, 583 (62\%), reported that such issues had never been addressed during their medical education.

\section{Potential consequences of experiencing moral dis- tressing situations}

Of all participants, 247 (26\%) considered leaving medical school and, among these, 33 (13\%) were considering leaving it at present due to moral distress. At some point, $258(28 \%)$ of 939 students thought about choosing a nonclinical specialty due to moral distress.

The composite score of moral distress among students who considered leaving medical school (median 97; IQR 58 - 142) was higher than in students that never thought about that (median 77; IQR 38 - 108) $(p<0.001)$. Among students who were considering leaving, the composite score of moral

Table 2 - Occurrence rates and intensity scores for potentially morally distressing situations

\begin{tabular}{|c|c|c|c|c|}
\hline & Potentially morally distressing situations & $\begin{array}{l}\text { Frequency } \\
\quad \%(n)\end{array}$ & $\begin{array}{l}\text { Experienced } \\
\text { Intensity } \\
\text { median (IQR) }\end{array}$ & $\begin{array}{l}\text { Anticipated } \\
\text { Intensity } \\
\text { median (IQR) }\end{array}$ \\
\hline 3 & $\begin{array}{l}\text { Sentir-se pressionado a pedir ou cumprir um pedido de exames e } \\
\text { tratamentos que considera serem desnecessários ou inadequados. } \\
\text { Feel pressured to order or carry out orders for what I consider to be } \\
\text { unnecessary or inappropriate tests and treatments. }\end{array}$ & 75 (705) & $2(1-3)$ & $2(0-3)$ \\
\hline 4 & $\begin{array}{l}\text { Estar impossibilitado de prestar os melhores cuidados possíveis devido a } \\
\text { pressões da administração ou seguradoras para reduzir custos. } \\
\text { Be unable to provide optimal care due to pressures from administrators or } \\
\text { insurers to reduce costs. }\end{array}$ & $69(644)$ & $3(3-4)$ & $3(1-4)$ \\
\hline 5 & $\begin{array}{l}\text { Continuar a prestar um tratamento agressivo a uma pessoa que muito } \\
\text { provavelmente morrerá, independentemente deste tratamento, quando } \\
\text { ninguém toma a decisão de o suspender. } \\
\text { Continue to provide aggressive treatment for a person who is most likely } \\
\text { to die regardless of this treatment when no one will make a decision to } \\
\text { withdraw it. }\end{array}$ & $55(517)$ & $3(2-4)$ & $3(0-4)$ \\
\hline 8 & $\begin{array}{l}\text { Participar em cuidados que causam sofrimento desnecessário ou não } \\
\text { aliviam adequadamente a dor ou outros sintomas. } \\
\text { Participate in care that causes unnecessary suffering or does not } \\
\text { adequately relieve pain or symptoms. }\end{array}$ & $50(473)$ & $3(2-4)$ & $4(0-4)$ \\
\hline 9 & $\begin{array}{l}\text { Observar os cuidados ao doente serem afetados devido à falta da sua } \\
\text { continuidade. } \\
\text { Watch patient care suffer because of a lack of provider continuity. }\end{array}$ & 74 (695) & $3(2-4)$ & $2(0-3)$ \\
\hline 17 & $\begin{array}{l}\text { Vivenciar comprometimento dos cuidados ao doente devido a falta de } \\
\text { recursos/equipamento/capacidade de camas. } \\
\text { Experience compromised patient care due to lack of resources/equipment/ } \\
\text { bed capacity. }\end{array}$ & $84(785)$ & $3(3-4)$ & $3(0-4)$ \\
\hline 19 & $\begin{array}{l}\text { Sentir os cuidados ao doente comprometidos por excesso de burocracia. } \\
\text { Have excessive documentation requirements that compromise patient } \\
\text { care. }\end{array}$ & $84(784)$ & $3(2-4)$ & $3(0-3)$ \\
\hline 20 & $\begin{array}{l}\text { Temer represálias se falar com franqueza. } \\
\text { Fear retribution if I speak up. }\end{array}$ & $73(684)$ & $3(2-4)$ & $2(0-3)$ \\
\hline 27 & $\begin{array}{l}\text { Trabalhar com membros da equipa que não tratam doentes vulneráveis } \\
\text { ou estigmatizados com dignidade e respeito. } \\
\text { Work with team members who do not treat vulnerable or stigmatized } \\
\text { patients with dignity and respect. }\end{array}$ & $58(544)$ & $4(3-4)$ & $3(0-4)$ \\
\hline
\end{tabular}




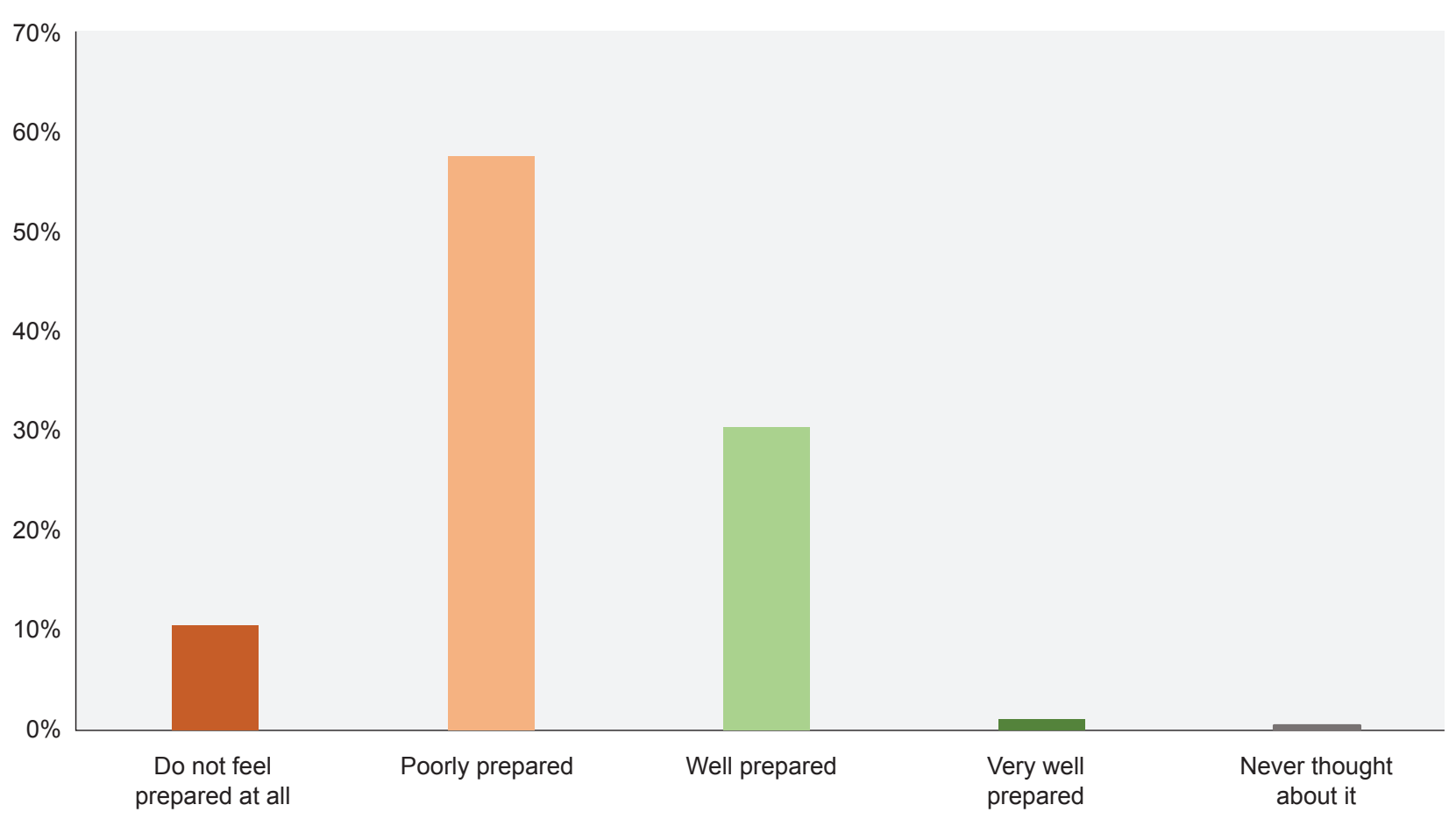

Figure 2 - How well-prepared participants felt handling a morally distressing situation

distress was also statistically significantly higher (median 118; IQR 92 - 169.5) than in students who were not considering it at the present time (median 78; IQR 41.75 - 115) ( $p$ $<0.001)$.

There were similar findings with students who thought about choosing a non-clinical specialty due to moral distress, presenting a higher score of moral distress (median 98; IQR 58 - 145) than students who never considered that (median 77; IQR 38 - 108) $(p<0.001)$.

\section{Group differences}

There was no statistically significant difference $(p=$ 0.52 ) in composite score of moral distress among genders [female - median 80 (IQR 42 - 120); male - median 77 (IQR 47.5 - 104)].

Sixth year medical students (median 96; IQR 58 - 136) showed a statistically significantly higher score of moral distress than students from the fourth $(p<0.001)$ and the fifth $(p<0.001)$ years. There was no statistically significant difference among fourth (median 77; IQR 26 - 112) and fifth (median 67; IQR 36.25 - 102) year students $(p=0.86$ ).

Some statistically significant differences in composite score of moral distress were observed between the different medical schools (Table 3). The three medical schools in northern Portugal reported lower levels of experienced moral distress when compared with the remaining ones. UBI medical school did not show levels that were statistically significantly different compared to other schools.

Participants who addressed this topic, $(n=357,38 \%)$ during their medical education did not show scores of moral distress that had statistically significant differences $(p=$ 0.20 ) compared to participants who had never addressed it.

\section{DISCUSSION}

One of the most relevant findings of this study was that most medical students had already experienced a significant number of morally distressing situations.

The most frequent situations reported by participants include root causes at all levels (patient, team and system are the three main identified sources of moral distress ${ }^{21}$ ).

Patient-level causes were not reported as causing high levels of moral distress. This may be explained by the fact that all participants were students. They may have witnessed patient-level situations, considering it frequent, but those did not occur directly with them since they are not yet responsible for medical decisions at this level.

New root causes were not identified in this study as write-in items added by participants reported situations that can be included in items already considered in the questionnaire.

\section{Patient, team and system-level root causes}

Situations regarding futile care and inadequate pain control were already identified by other studies as one of the main causes of moral distress, ${ }^{28-30}$ reinforcing the view that moral distress often describes an ethical issue and its psychological consequences. ${ }^{6,14}$ Students seem to be more vulnerable in situations where they recognize a direct negative impact on patient care even when these situations occur with low frequency. The expectations of students that medicine can always cure may contribute to this source of distress. Physicians should share their ethical issues with their students and reveal their concerns, even if a solution for more complex problems is not found. ${ }^{31}$ 
Table 3 - Composite score of moral distress by medical school

\begin{tabular}{|c|c|c|c|}
\hline Medical school & $\begin{array}{l}\text { Composite score of moral distress } \\
\text { Median [IQR] }\end{array}$ & & $p$ value \\
\hline \multirow[t]{7}{*}{ ICBAS } & $78(25-122.25)$ & & \\
\hline & & FMUC & $0.02^{\mathrm{a}}$ \\
\hline & & U. Minho & 0.86 \\
\hline & & FMUL & $0.01^{\mathrm{a}}$ \\
\hline & & NMS | FCM & $0.01^{\mathrm{a}}$ \\
\hline & & UBI & 0.47 \\
\hline & & FMUP & 0.98 \\
\hline \multirow[t]{7}{*}{ FMUC } & $97(58-113)$ & & \\
\hline & & ICBAS & $0.02^{\mathrm{a}}$ \\
\hline & & U. Minho & 0.06 \\
\hline & & FMUL & 0.89 \\
\hline & & NMS | FCM & 0.96 \\
\hline & & UBI & 0.33 \\
\hline & & FMUP & 0.07 \\
\hline \multirow[t]{7}{*}{ U. Minho } & $67(58-136)$ & & \\
\hline & & ICBAS & 0.86 \\
\hline & & FMUC & 0.06 \\
\hline & & FMUL & $0.02^{\mathrm{a}}$ \\
\hline & & NMS | FCM & $0.02^{\mathrm{a}}$ \\
\hline & & UBI & 0.58 \\
\hline & & FMUP & 0.91 \\
\hline \multirow[t]{7}{*}{ FMUP } & $67(38-132)$ & & \\
\hline & & ICBAS & 0.98 \\
\hline & & FMUC & 0.07 \\
\hline & & U. Minho & 0.91 \\
\hline & & FMUL & $0.03^{a}$ \\
\hline & & NMS|FCM & $0.03^{a}$ \\
\hline & & UBI & 0.54 \\
\hline \multirow[t]{3}{*}{ FMUL } & $89(67-132)$ & & \\
\hline & & NMS | FCM & 0.92 \\
\hline & & UBI & 0.25 \\
\hline \multirow[t]{2}{*}{ NMS|FCM } & $92(61.25-115)$ & & \\
\hline & & UBI & 0.28 \\
\hline UBI & $79(64-90)$ & & \\
\hline
\end{tabular}

a: Statistically significant difference.

FMUP: Faculdade de Medicina da Universidade do Porto; FMUL: Faculdade de Medicina da Universidade de Lisboa; FMUC: Faculdade de Medicina da Universidade de Coimbra; ICBAS: Instituto de Ciências Biomédicas Abel Salazar; NMS|FCM: Nova Medical School | Faculdade de Ciências Médicas; UBI: Universidade da Beira Interior; U. Minho: Universidade do Minho.

The lack of cooperation and good communication between team members seems to be a source of moral distress for students. Due to their low position in the hierarchy, they may remain silent because they fear that voicing concerns could negatively impact their evaluations or make instructors feel their authority is being questioned. ${ }^{32}$ Promoting equal participation of the different elements in the discussion of clinically challenging situations, helping to create an environment that encourages the willingness of students to speak up, ${ }^{11,13}$ can help not only students but all healthcare professionals to address morally distressing situations.

Our institutions, with well-defined hierarchical and bureaucratic organizational models, seem to contribute to this phenomenon. Students may feel restrictions to their freedom in providing the best care to patients. ${ }^{3,33,34}$ Therefore, creating mechanisms that allow adequate flexibility and reduction of time spent with bureaucratic processes may be an effective approach to reduce levels of moral distress. ${ }^{32,35}$ At the same time, the inability to provide the best care due to lack of resources could be prevented by improving 
working conditions, ${ }^{36}$ namely ensuring there are no shortages of material and all the means for treating patients are guaranteed.

\section{Handling a morally distressing situation}

Our data showed that most students felt poorly prepared to handle morally distressing situations. Indeed, there were no differences in levels of moral distress between students who stated addressing this topic in classes and those who did not. One could argue that although some schools recognize it is important to address this issue, the approaches used do not seem to have a protective effect on their students. Once morally distressing situations have occurred, a moral wound may remain as a result from the violation of moral values - "moral residue". 6,37 Therefore, it may be important to do more than discuss the topic and provide students with skills to deal with these situations.

\section{Potential consequences of experiencing moral dis- tressing situations}

Moral distress was higher in participants who considered leaving medical school and in participants who thought about choosing a non-clinical specialty. This is well aligned with the current literature that shows higher MMD-HP scores for those considering leaving their position. ${ }^{4,21}$ Medical school dropouts constitute a direct economic loss to society, may compromise healthcare and represent a loss of useful contributions to the medical profession. ${ }^{38}$ Moreover, student dropout may be symptomatic of preventable malfunctioning in medical education. ${ }^{39}$

These data, along with the poor preparation reported by students, represent new and valuable knowledge to the literature, reporting how students feel about the theme, the lack of/ineffective approaches to the topic by medical schools and exposing the potencial consequences of continued moral distress over time.

\section{Differences between year of attendance}

Higher levels of moral distress in students from the sixth year seem to support the concepts of 'crescendo effect'21 and 'moral residue'. 6,28 The latter contributes to a higher baseline level of distress to which subsequent situations add their distress. ${ }^{15}$ Consequently, the phenomenon of moral distress may have a cumulative effect over time. ${ }^{28}$ Nonetheless, due to the nature of its curriculum, the students in the final year are more exposed to patients, which, along with their greater clinical knowledge compared to younger students, can contribute to and magnify this effect.

\section{Differences between medical schools}

Differences between medical schools are not explained by the approach or lack of approach to the theme, so other causes should be considered. Ethics curricula are widespread, reflecting the prevalence of ethical issues in clinical practice, ${ }^{39}$ but its content and distribution is not homogeneous across schools. The main difference observed is that in the medical schools in northern Portugal, the ethics subjects are integrated in the first clinical years, while in other schools the same subjects are part of the first years of medical education. This could have a protective effect towards students in northern Portugal and could potentially cause deficits in skills that may leave the other students more vulnerable to the impact of moral distress. ${ }^{15}$

Our data seem to support that all medical schools could consider creating a strong ethics and humanities curricula alongside clinical practice, including didactic programs on normative ethics. This could potentially increase not only self-confidence but also the willingness to speak up and engage in morally responsible actions. ${ }^{11,15}$

\section{Strengths and limitations}

The participation of students from seven out of eight Portuguese medical schools included in the study enabled a robust assessment of this issue at a national level, but also a robust comparison with the international literature.

The retrospective design of the study is a limitation, since the participants had to resort to memory in order to score each situation.

The response rate of $22 \%$ is quite reasonable considering the web-based design but can limit the generalizability of results. Perhaps students who participated in the study have different levels of moral sensitivity than those who did not participate. However, the widespread distribution of participants is a strength of this study.

The last two weeks of data collection period coincided with the notification of the first cases of COVID-19 in Portugal. All medical schools suspended their activity since the first case was notified, so these extraordinary circumstances should not have affected the results of the study.

\section{CONCLUSION}

Our study showed that most Portuguese medical students had already experienced morally distressing situations as early as during the first years of clinical practice. These experiences may promote school dropouts and may affect the way future healthcare professionals deal with clinical challenging situations.

The recognition of this phenomenon by medical educators might be the first step to mitigate its effects. Approaches to reduce moral distress may include strategies to help medical students identify and use their inner resources (i.e., emotional intelligence), increasing their empowerment and self-confidence.

The curricula of medical schools might benefit from the promotion of a strong mentoring program for students in their clinical years, which can help to promote trust and open communication and may have a strong positive effect on the level of empathy among medical students. Including ethics subjects alongside clinical ones and promoting their interaction may also be a good approach to reduce moral distress.

Despite the extensive literature showing high levels of moral distress among healthcare professionals, this study shows that the phenomenon occurs early in medical school. 
This emphasizes the importance of a critical review of medical education, particularly in ethics and humanities curricula, reducing the harmful effects of preventable psychological phenomena in clinical practice and in the lives of healthcare professionals all over the world.

Future research should address the differences in the curricula adopted by different medical schools in order to assess which model(s) might have the best effect on reducing moral distress. It should also address if students who experienced high levels of moral distress are at higher risk of burnout, especially considering these unprecedented times.

\section{OBSERVATIONS}

This study was developed as a master's thesis, and it was presented by the first author of the study to obtain a master's degree in Medicine.

\section{AUTHORS CONTRIBUTION}

MD: Design of the study; data acquisition and statistics process; draft and critical review of the paper.

CT, BA: Design of the study; draft and critical review of the paper.

\section{REFERENCES}

1. Jameton A. Nursing practice: The ethical issues. Englewood Cliffs: Prentice-Hall; 1984.

2. Fourie C. Moral distress and moral conflict in clinical ethics. Bioethics. 2015;29:91-7.

3. Jameton A. What moral distress in nursing history could suggest about the future of health care. AMA J Ethics. 2017;19:617-28.

4. Corrado AM, Molinaro ML. Moral distress in health care professionals. UWOMJ. 2017;86:32-4.

5. Fourie C. Who Is experiencing what kind of moral distress? Distinctions for moving from a narrow to a broad definition of moral distress. AMA J Ethics. 2017;19:578-84.

6. Epstein EG, Hamric AB. Moral distress, moral residue, and the crescendo effect. J Clin Ethics. 2009;20:330-42.

7. Markose A, Krishnan R, Ramesh M. Medical ethics. J Pharm Bioallied Sci. 2016;8:S1-4.

8. Genuis SJ. Dismembering the ethical physician. Postgrad Med J. 2006;82:233-8.

9. Hajar R. The physician's oath: historical perspectives. Heart Views. 2017;18:154-9.

10. Austin W. What is the role of ethics consultation in the moral habitability of health care environments? AMA J Ethics. 2017;19:595-600.

11. Thurn T, Anneser J. Medical students' experiences of moral distress in end-of-life care. J Palliat Med. 2020;23:116-20.

12. Wiggleton C, Petrusa E, Loomis K, Tarpley J, Tarpley M, O'Gorman ML, et al. Medical students' experiences of moral distress: development of a web-based survey. Acad Med. 2010;85:111-7.

13. Weber E, Gray S. How should integrity, preservation and professional growth be balanced during trainees' professionalization? AMA J Ethics. 2017;19:544-9.

14. Rosenthal MS, Clay M. Initiatives for responding to medical trainees' moral distress about end-of-life cases. AMA J Ethics. 2017;19:585-94.

15. Berger JT. Moral distress in medical education and training. J Gen Intern Med. 2014;29:395-8.

16. Hamric AB, Borchers, CT, Epstein EG. Development and testing of an instrument to measure moral distress in healthcare professionals. AJOB Primary Research. 2012;3:1-9.

17. Allen R, Judkins-Cohn $T$, deVelasco R, Forges $E$, Lee R, Clark L, et al. Moral distress among healthcare professionals at a health system. JONAS Healthc Law Ethics Regul. 2013;15:111-8; quiz 9-20.

18. Trotochaud K, Coleman JR, Krawiecki N, McCracken C. Moral distress in pediatric healthcare providers. J Pediatr Nurs. 2015;30:908-14.

19. Dodek PM, Wong H, Norena M, Ayas N, Reynolds SC, Keenan SP, et

\section{PROTECTION OF HUMANS AND ANIMALS}

The authors declare that the procedures were followed according to the regulations established by the Clinical Research and Ethics Committee and to the Helsinki Declaration of the World Medical Association updated in 2013.

\section{DATA CONFIDENTIALITY}

The authors declare having followed the protocols in use at their working center regarding patients' data publication.

\section{COMPETING INTERESTS}

The authors had no competing interests.

\section{FUNDING SOURCES}

BA is funded by the National Institute for Health Research (NIHR) Applied Research Collaboration East of England (ARC EoE) programme. The views expressed are those of the author(s) and not necessarily those of the NHS, the NIHR or the Department of Health and Social Care. The funding organizations had no role in the design of the study, collection, analysis, interpretation of the data, or writing of the manuscript.

al. Moral distress in intensive care unit professionals is associated with profession, age, and years of experience. J Crit Care. 2016;31:178-82.

20. Lamiani G, Setti I, Barlascini L, Vegni E, Argentero P. Measuring moral distress among critical care clinicians: validation and psychometric properties of the Italian moral distress scale-revised. Crit Care Med. 2017;45:430-7

21. Epstein EG, Whitehead PB, Prompahakul C, Thacker LR, Hamric AB. Enhancing understanding of moral distress: the measure of moral distress for health care professionals. AJOB Empir Bioeth. 2019;10:11324

22. Slotnick HB, Shershneva MB. Use of theory to interpret elements of change. J Contin Educ Health Prof. 2002;22:197-204.

23. Bordage G. Conceptual frameworks to illuminate and magnify. Med Educ. 2009;43:312-9

24. Eysenbach G. Improving the quality of web surveys: the Checklist for Reporting Results of Internet E-Surveys (CHERRIES). J Med Internet Res. 2004;6:e34

25. Mokkink LB, Terwee CB, Patrick DL, Alonso J, Stratford PW, Knol DL, et al. The COSMIN study reached international consensus on taxonomy, terminology, and definitions of measurement properties for healthrelated patient-reported outcomes. J Clin Epidemiol. 2010;63:737-45.

26. Beaton DE, Bombardier C, Guillemin F, Ferraz MB. Guidelines for the process of cross-cultural adaptation of self-report measures. Spine. 2000;25:3186-91.

27. Wild D, Grove A, Martin M, Eremenco S, McElroy S, Verjee-Lorenz A, et al. Principles of good practice for the translation and cultural adaptation process for patient-reported outcomes (PRO) measures: report of the ISPOR Task Force for Translation and Cultural Adaptation. Value Health. 2005;8:94-104

28. Mobley MJ, Rady MY, Verheijde JL, Patel B, Larson JS. The relationship between moral distress and perception of futile care in the critical care unit. Intensive Crit Care Nurs. 2007;23:256-63.

29. Rice EM, Rady MY, Hamrick A, Verheijde JL, Pendergast DK. Determinants of moral distress in medical and surgical nurses at an adult acute tertiary care hospital. J Nurs Manag. 2008;16:360-73.

30. Maffoni M, Argentero P, Giorgi I, Hynes J, Giardini A. Healthcare professionals' moral distress in adult palliative care: a systematic review. BMJ Support Palliat Care. 2019;9:245-54.

31. Howe EG $3^{\text {rd }}$. How should physicians respond when the best treatment for an individual patient conflicts with practice guidelines about the use of a limited resource? AMA J Ethics. 2017;19:550-7.

32. Miller BM. How should resident physicians respond to patients' 
discomfort and students' moral distress when learning procedures in academic medical settings? AMA J Ethics. 2017;19:537-43.

33. Papathanassoglou ED, Karanikola MN, Kalafati M, Giannakopoulou M, Lemonidou C, Albarran JW. Professional autonomy, collaboration with physicians, and moral distress among European intensive care nurses. Am J Crit Care. 2012;21:e41-52.

34. Pendry PS. Moral distress: recognizing it to retain nurses. Nurs Econ. 2007;25:217-21.

35. Atabay G, Cangarli BG, Penbek S. Impact of ethical climate on moral distress revisited: multidimensional view. Nurs Ethics. 2015;22:103-16.

36. Morley G, Ives J, Bradbury-Jones C. Moral Distress and Austerity:
An Avoidable Ethical Challenge in Healthcare. Health Care Anal. 2019;27(3):185-201.

37. Vannatta J, Schleifer R, Crow S. Part six: The role of narrative in the everyday practice of medicine ethics and mistakes in the everyday practice of medicine. J Okla State Med Assoc. 2009;102:301-4.

38. O'Neill LD, Wallstedt B, Eika B, Hartvigsen J. Factors associated with dropout in medical education: a literature review. Med Educ. 2011;45:440-54.

39. Carrese JA, McDonald EL, Moon M, Taylor HA, Khaira K, Catherine Beach $\mathrm{M}$, et al. Everyday ethics in internal medicine resident clinic: an opportunity to teach. Med Educ. 2011;45:712-21. 